\title{
Inisiasi, pertumbuhan, dan perkembangan kalus embriogenik tanaman stevia (Stevia rebaudiana)
}

\author{
Initiation, growth, and development of embryogenic calli of stevia (Stevia rebaudiana)
}

Masna Maya SINTA*), Rizka Tamania SAPTARI \& SUMARYONO

Pusat Penelitian Bioteknologi dan Bioindustri Indonesia, Jl Taman Kencana No.1, Bogor 16128, Indonesia

Diterima tgl 08 Juli 2021 / disetujui tgl 12 Oktober 2021

\begin{abstract}
The leaves of sweetener plant Stevia rebaudiana contain secondary metabolites of steviol glycosides which are very sweet, with no calorie and zero glycemic index. Propagation of stevia by seeds is ineffective due to its low germination rate and diverse progenies. The tissue culture of stevia can be used to mass propagate rapidly and is commonly conducted by shoot multiplication. Up to now, the technology of somatic embryogenesis (SE) in stevia has not been successful yet. SE is developed to increase the production scale, rejuvenate clonal-propagated plants, and plant genetic transformation. The research objective was to develop protocols for the initiation, proliferation, and development of embryogenic calli of stevia as potential materials for SE. The explants used were young leaves, nodes, and internodes of axenic plantlets of stevia BX clone. The explants were cultured on MS solid media containing different concentrations of auxin and cytokinin for callus initiation. Callus emerged after 2-3 weeks of culture. The calli obtained were proliferated by subculturing several times as material stocks for indirect SE. MS solid media added with $1 \mu M$ 3,4-D and $16 \mathrm{mM} \mathrm{CaCl} 2$ gave the highest callus multiplication rate (4.7 times in 3 weeks). The selection of embryogenic calli was made continuously to obtain a pure line of embryogenic calli. Three types of calli attained were friable, fast-growing, yellowish calli, shiny nodular calli, and greenish nodular calli. Histological studies revealed that cells of the nodular calli had been differentiated to potentially formed somatic embryos.
\end{abstract}

[Keywords: callus initiation, callus cell line, callus proliferation, stevia]

\section{Abstrak}

Daun tanaman pemanis Stevia rebaudiana mengandung glikosida steviol yang sangat manis, tanpa kalori dan memiliki indeks glikemik nol. Perbanyakan stevia dengan biji tidak efektif karena rendahnya daya kecambah biji dan turunannya sangat beragam. Kultur jaringan stevia dapat dilakukan untuk perbanyakan massal secara cepat dan umumnya dilakukan dengan multiplikasi tunas. Sampai saat ini teknologi embriogenesis somatik (SE) pada stevia belum berhasil dilakukan. SE dikembangkan untuk meningkatkan skala produksi, untuk rejuvenasi tanaman yang diperbanyak secara vegetatif, serta sebagai bahan untuk transformasi genetik tanaman. Tujuan penelitian adalah untuk mengembangkan protokol inisiasi, proliferasi dan perkembangan kalus embriogenik pada tanaman stevia sebagai bahan potensial untuk SE. Eksplan yang digunakan untuk kultur in vitro stevia adalah daun muda, buku, dan ruas dari planlet steril stevia klon BX. Eksplan tersebut dikultur pada medium padat MS yang mengandung berbagai konsentrasi auksin dan sitokinin untuk inisiasi kalus. Kalus tumbuh 2-3 minggu setelah kultur. Kalus yang diperoleh kemudian diperbanyak beberapa kali sebagai bahan sediaan untuk SE tak-langsung. Medium MS ditambah dengan 3,4-D $1 \mu \mathrm{M}$ dan $\mathrm{CaCl}_{2}$. $16 \mathrm{mM}$ menghasilkan laju multiplikasi tertinggi kalus (4,7 kali dalam 3 minggu). Pada setiap kali subkultur dilakukan seleksi kalus embriogenik terus-menerus sehingga diperoleh lini sel kalus embriogenik. Tiga jenis kalus yang diperoleh adalah kalus remah yang berwarna kekuningan dan tumbuh pesat, kalus noduler yang mengkilap, dan kalus noduler berwarna kehijauan. Kajian histologi menunjukkan bahwa sel-sel pada kalus noduler telah terdiferensiasi yang berpotensi membentuk embrio somatik.

[Kata kunci: inisiasi kalus, lini sel kalus, proliferasi kalus, stevia]

\section{Pendahuluan}

Stevia (Stevia rebaudiana Bertoni) dikenal sebagai tanaman pemanis dengan kandungan glikosida steviol (GS) terutama pada daun (Brandle \& Telmer, 2007). GS sangat manis 100450 kali dibandingkan sukrosa (Cramer \& Ikan, 1986), tanpa kalori, dan mempunyai indeks glikemik nol (Pérez et al., 2016). Selain digunakan

${ }^{*}$ Korespondensi penulis: mayasinta77@gmail.com 
sebagai pemanis, stevia dilaporkan memiliki kemampuan sebagai antioksidan, antimikroba, antiinflamasi, dan antivirus (Oliveira et al., 2013; Gawel-Beben et al., 2015; Lemus-Mondaca et al., 2018). Terdapat 34 jenis GS yang telah diidentifikasi pada stevia (Ceunen \& Geuns, 2013), dua diantaranya merupakan komponen utama yaitu steviosida dan rebaudiosida A (reb A) (Prakash et al., 2014).

Populasi tanaman budidaya stevia di lapang sangat tinggi, yaitu antara 70 sampai 100 ribu tanaman per hektar (Kumar et al., 2014; Mengesha et al., 2014; Parris \& Shock, 2016), sehingga diperlukan bibit dalam jumlah banyak. Perbanyakan stevia secara konvensional melalui biji kurang efektif karena rendahnya tingkat perkecambahan biji (Goettemoeller \& Ching, 1999; Raina et al., 2013; Ozyigit et al., 2015) dan terjadinya self-incompatibility (Yadav et al., 2014). Keragaman genetik dari perkawinan silang menyebabkan keragaman hasil produksi. Oleh karena itu, teknik kultur jaringan diperlukan untuk memproduksi bibit unggul stevia secara klonal dengan cepat dan massal.

Kultur jaringan stevia biasanya dilakukan melalui multiplikasi tunas dengan media MS (Murashige \& Skoog, 1962) menggunakan daun muda atau bagian bunga sebagai sumber eksplan. Kultur jaringan melalui embriogenesis somatik (somatic embryogenesis, SE) memiliki beberapa keunggulan dibandingkan dengan metode multiplikasi tunas dan organogenesis. Keunggulan tersebut yakni laju multiplikasi lebih tinggi, memungkinkan untuk otomatisasi dan scale-up dalam kultur cair (Wang et al., 2019; Egertsdotter et al., 2019), bibit yang dihasilkan mempunyai akar tunggang sehingga lebih kokoh dan tahan cekaman kekeringan (Egertsdotter et al., 2019), serta embrio somatik yang diperoleh dapat digunakan untuk transformasi genetik dan mutagenesis dalam pemuliaan tanaman (Ribas et al., 2011; Pikulthong et al., 2016; Pires et al., 2020). Selain itu, SE juga bermanfaat dalam rejuvenasi (peremajaan) (Lelu-Walter et al., 2018) tanaman yang diperbanyak secara vegetatif secara berulang selama bertahun-tahun misalnya okulasi pada tanaman karet (Montoro et al., 2012).

Penelitian SE stevia telah banyak dilakukan (Banerjee \& Sarkar, 2008; 2010; Janarthanam et al., 2009; Lopez-Arellano et al., 2015; Keshvari et al., 2018) hingga diperoleh kalus embriogenik atau embrio somatik. Salah satunya yaitu penelitian SE stevia oleh Banerjee \& Sarkar (2008) yang menggunakan media dengan penambahan sianobakteri sebagai pengganti MS dan berhasil menginduksi pembentukan embrio somatik stevia hingga $60 \%$ dan maturasi embrio somatik mencapai 96\%. Janartanam et al. (2009) menginduksi kalus stevia dari buku dan terbentuk tunas namun tanpa melalui pembentukan embrio yang jelas, sedangkan Keshvari et al. (2018) menginduksi kalus stevia pada media B5 hingga didapatkan kalus globuler tapi tidak berkembang ke tahap selanjutnya. Lopez-Arellano et al. (2015) melaporkan pembentukan embrio somatik dan regenerasi menjadi planlet dari kultur protoplas stevia. Berdasarkan beberapa hasil penelitian terdahulu tersebut, sampai saat ini belum pernah dilaporkan adanya keberhasilan embrio somatik yang diregenerasikan menjadi planlet dengan prosedur yang berulang. Keberhasilan SE stevia merupakan terobosan dalam kultur jaringan tanaman stevia yang dapat dimanfaatkan untuk perbanyakan massal, pemuliaan tanaman, dan rejuvenasi tanaman. Tujuan penelitian ini adalah untuk mengembangkan protokol inisiasi, proliferasi, dan perkembangan kalus embriogenik pada tanaman stevia sebagai bahan potensial untuk SE.

\section{Bahan dan Metode}

\section{Induksi kalus}

Eksplan yang digunakan pada penelitian ini adalah daun, ruas, dan buku stevia aksenik klon BX koleksi Pusat Penelitian Bioteknologi dan Bioindustri Indonesia (PPBBI), Bogor, Indonesia. Klon ini merupakan salah satu klon unggulan dengan vigor tanaman yang baik, panen 8 kali dalam setahun, produktivitas lapang 4,9 ton daun kering ha tahun $^{-1}$ serta memiliki kandungan steviosida dan reb A sebesar 10,32\% dari berat kering daun (Sinta \& Sumaryono, 2019). Induksi kalus dilakukan pada media dasar MS (Murashige \& Skoog, 1962) dan sukrosa 3\%, gelzan 3,5 $\mathrm{gL}^{-1}$ dengan perlakuan auksin yaitu dengan penambahan 2,4-Diklorofenoksi asetat (2,4-D) 2,5 $\mu \mathrm{M}$ dan asam 3,4-Diklorofenoksi asetat (3,4-D) dengan konsentrasi 1; 2,5 dan $5 \mu \mathrm{M}$, media MS tanpa hormon sebagai kontrol. Empat potong eksplan berukuran 0,5-1 cm dikultur pada medium dalam setiap cawan Petri, dengan ulangan sebanyak 10 cawan Petri. Sebelumnya media disterilisasi dalam autoklaf $121{ }^{\circ} \mathrm{C}$ selama 20 menit, kemudian dituang ke dalam cawan Petri berdiameter 5,5 cm sebanyak $12,5 \mathrm{~mL}$, dengan $\mathrm{pH}$ media 5,7. Eksplan yang telah ditanam selanjutnya diinkubasi pada ruang gelap selama 4 minggu. Pengamatan kemunculan kalus dilakukan setiap minggu.

\section{Kultur dan proliferasi kalus}

Kalus yang diperoleh disubkultur pada media yang sama setiap 3 minggu. Pemurnian lini sel kalus (cell line) embriogenik dilakukan dengan memilih kalus remah (friable) menggunakan mikroskop. Kalus remah dengan diameter $0,4 \mathrm{~cm}$ selanjutnya diproliferasi pada medium MS dengan penambahan $\mathrm{CaCl}_{2}(2,4,8,16 \mathrm{mM})$ dan auksin (2,4-D 2,5 $\mu \mathrm{M}$ dan 3,4-D dengan konsentrasi 1; 2,5 dan $5 \mu \mathrm{M}$ ) untuk meningkatkan laju pembentukan kalus embriogenik. Tiap perlakuan diulang 5 kali dengan masing-masing berisi 5 clump per cawan Petri. Pengamatan dilakukan terhadap jenis kalus (kompak, remah, noduler, embriogenik) dan ukurannya. 


\section{Induksi kalus embriogenik dengan sitokinin}

Kalus remah yang telah diperbanyak pada penelitian sebelumnya, digunakan sebagai bahan induksi kalus embriogenik. Kalus embriogenik diinduksi pada media MS, sukrosa 3\% dengan penambahan 3,4 D 0,5 $\mu \mathrm{M}$ dan berbagai jenis sitokinin (kinetin, 2-iP, BA) dengan konsentrasi 5, 10 , dan $20 \mu \mathrm{M}$. Kalus yang ditanam pada media tanpa penambahan sitokinin digunakan sebagai kontrol.

Induksi kalus embriogenik dengan jenis dan konsentrasi karbon yang berbeda

Kalus remah dikulturkan pada media dasar MS ditambah 3,4-D 0,5 $\mu \mathrm{M}$ dan kinetin $5 \mu \mathrm{M}$. Induksi kalus embriogenik dilakukan dengan perlakuan beberapa sumber karbon (sukrosa, maltosa, glukosa, dan manitol) pada konsentrasi masingmasing 30, 60, 90, dan $120 \mathrm{gL}^{-1}$. Perlakuan sukrosa $30 \mathrm{gL}^{-1}$ digunakan sebagai kontrol.

Induksi kalus embriogenik dengan pencucian dalam medium cair dan penambahan IBA

Kalus remah stevia klon BX asal buku dari penelitian sebelumnya disubkultur ke medium cair $1 / 2$ makro MS tanpa hormon dengan penambahan hormon IBA $10 \mu \mathrm{M}$. Tujuannya untuk mencuci hormon yang telah terserap oleh eksplan dari perlakuan sebelumnya. Pencucian dilakukan selama satu minggu, pada labu Erlenmeyer $125 \mathrm{~mL}$ dengan penggojokan pada shaker dengan kecepatan 90 rpm. Masing-masing labu Erlenmeyer berisi 12,5 mL media dengan eksplan kalus remah sebanyak kurang lebih 0,2 g. Setelah pencucian, kalus disubkultur ke media padat $1 / 2$ makro MS tanpa hormon dan $1 / 2 \mathrm{MS}+$ IBA $10 \mu \mathrm{M}$. Pencucian dengan media tanpa hormon yang kemudian ditanam pada media padat tanpa IBA digunakan sebagai kontrol.

Pada percobaan induksi kalus embriogenik ini masing-masing dilakukan dengan 5 ulangan pada cawan Petri berisi 4 clump kalus. Pengamatan dilakukan pada minggu ke-3 (menjelang subkultur) terhadap perubahan yang terjadi pada kalus. Induksi kalus embriogenik dilakukan pada ruang gelap, selanjutnya kalus noduler yang dihasilkan dikultur pada ruang terang (pada suhu $26 \pm 2{ }^{\circ} \mathrm{C}$ dengan intensitas cahaya $20 \mu \mathrm{mol}$ foton $\mathrm{m}^{-2}$ detik $^{-1}$ dengan fotoperiode $\left.12 \mathrm{jam}\right)$ dalam media yang sama.

\section{Histologi}

Materi yang dianalisis histologi berupa kalus remah, kalus noduler, dan kalus embriogenik dari kultur stevia. Masing-masing material dimasukkan ke dalam botol flakon $25 \mathrm{~mL}$ berisi larutan fiksasi FAA (Formalin, Asam asetat, dan Alkohol), selanjutnya proses dehidrasi, infiltrasi, embedding, serta pembuatan dan penyimpanan blok paraplast mengikuti protokol standar histologi (Ruzin, 1999). Pengirisan preparat menggunakan mikrotom putar dengan ketebalan $10 \mu \mathrm{m}$, dan pewarnaan menggunakan Fast Green (Merck, Jerman) 1\% dalam alkohol 95\% selama 5 menit. Preparat histologi diamati di bawah mikroskop cahaya (Kruss, Jerman) dan didokumentasikan.

\section{Rancangan percobaan dan analisis data}

Penelitian dilakukan menggunakan rancangan acak lengkap dengan jumlah ulangan minimal 20 kali untuk inisiasi kalus. Perlakuan selanjutnya diulang minimal 5 kali dengan 5 clump kalus per cawan atau botol kultur. Data yang diperoleh diolah dengan analisis ragam (analysis of variance $=$ ANOVA). Apabila terdapat perbedaan faktor perlakuan yang nyata, maka perbedaan antarperlakuan diuji dengan uji jarak berganda Duncan pada taraf signifikansi $5 \%$.

\section{Hasil dan Pembahasan}

Induksi kalus

Kalus pada umumnya mulai muncul 2-3 minggu setelah tanam. Induksi kalus tertinggi terdapat pada eksplan ruas dalam media MS dengan $1 \mu \mathrm{M}$ 2,4-D dan 3,4-D $1 \mu \mathrm{M}$ (persentase induksi mencapai $100 \%$, Tabel 1). Kalus mampu terbentuk pada semua jenis eksplan yang ditanam pada media dengan penambahan auksin (Gambar 1a-c), namun eksplan yang ditanam pada media tanpa hormon tidak membentuk kalus sama sekali (Gambar 1d-f).

\section{Proliferasi dan seleksi kalus}

Kalus primer yang terbentuk (Gambar 2a) selanjutnya dipisahkan dari eksplan untuk tahap pemurnian. Pemurnian kalus dilakukan untuk memperoleh hanya sel-sel kalus yang memiliki potensi embriogenik, yaitu dengan cara menyeleksi sel-sel potensial dan memindahkannya ke media baru dengan komposisi yang sama. Pemurnian ini dilakukan dengan bantuan mikroskop stereo. Terdapat 2 jenis kalus yang muncul setelah proses seleksi ini yaitu kalus kompak dan kalus remah (Gambar 2b). Kalus remah diperoleh pada media dengan penambahan 2,4-D 2,5 $\mu \mathrm{M}$; serta 3,4-D $1 \mu \mathrm{M}$ dan 2,5 $\mu \mathrm{M}$, sedangkan media dengan penambahan $3,4-\mathrm{D} 5 \mu \mathrm{M}$ pada umumnya menghasilkan kalus kompak. Setelah melalui proses seleksi berulang, diperoleh lini sel kalus remah (friable) seperti pada Gambar 2c.

Seleksi kalus remah juga dilakukan pada SE karet terutama pada jalur long-term SE (Cailloux et al., 1996), kalus ini juga digunakan sebagai bahan penyimpanan kalus jangka panjang dengan kriopreservasi (Lardet et al., 2007). Seleksi kalus juga dilakukan pada kultur suspensi Artemisia Annua L. (Jin \& Keng, 2013), Boerhaavia paniculata Rich (Souza et al., 2014), Manihot esculenta Crantz (Apio et al., 2015), Grewia tenax (Dafalla et al., 2019), Sorghum bicolor L. (Ramulifho et al., 2019). Kalus remah memiliki 
Tabel 1. Persentase induksi kalus pada tiga jenis eksplan stevia klon BX pada umur 4 minggu

Table 1. Percentage of callus induction in three different explants of stevia clone BX after 4 weeks

\begin{tabular}{lccccc}
\hline \multirow{2}{*}{$\begin{array}{c}\text { Jenis eksplan } \\
\text { Explant type }\end{array}$} & \multicolumn{5}{c}{ Auksin (Auxin) } \\
\cline { 2 - 6 } & 0 & 2,4-D 2,5 $\mu \mathrm{M}$ & $3,4-\mathrm{D} 1,0 \mu \mathrm{M}$ & $3,4-\mathrm{D} 2,5 \mu \mathrm{M}$ & $3,4-\mathrm{D} 5 \mu \mathrm{M}$ \\
\hline & & -------- Induksi kalus (Callus induction) (\%) --------- & 96 \\
Ruas (Internode) & 0 & 100 & 98 & 96 & 74 \\
Buku (Node) & 0 & 94 & 92 & 96 & 98 \\
Daun (Leaf) & 0 & 91 & 100 & 96 \\
\hline
\end{tabular}
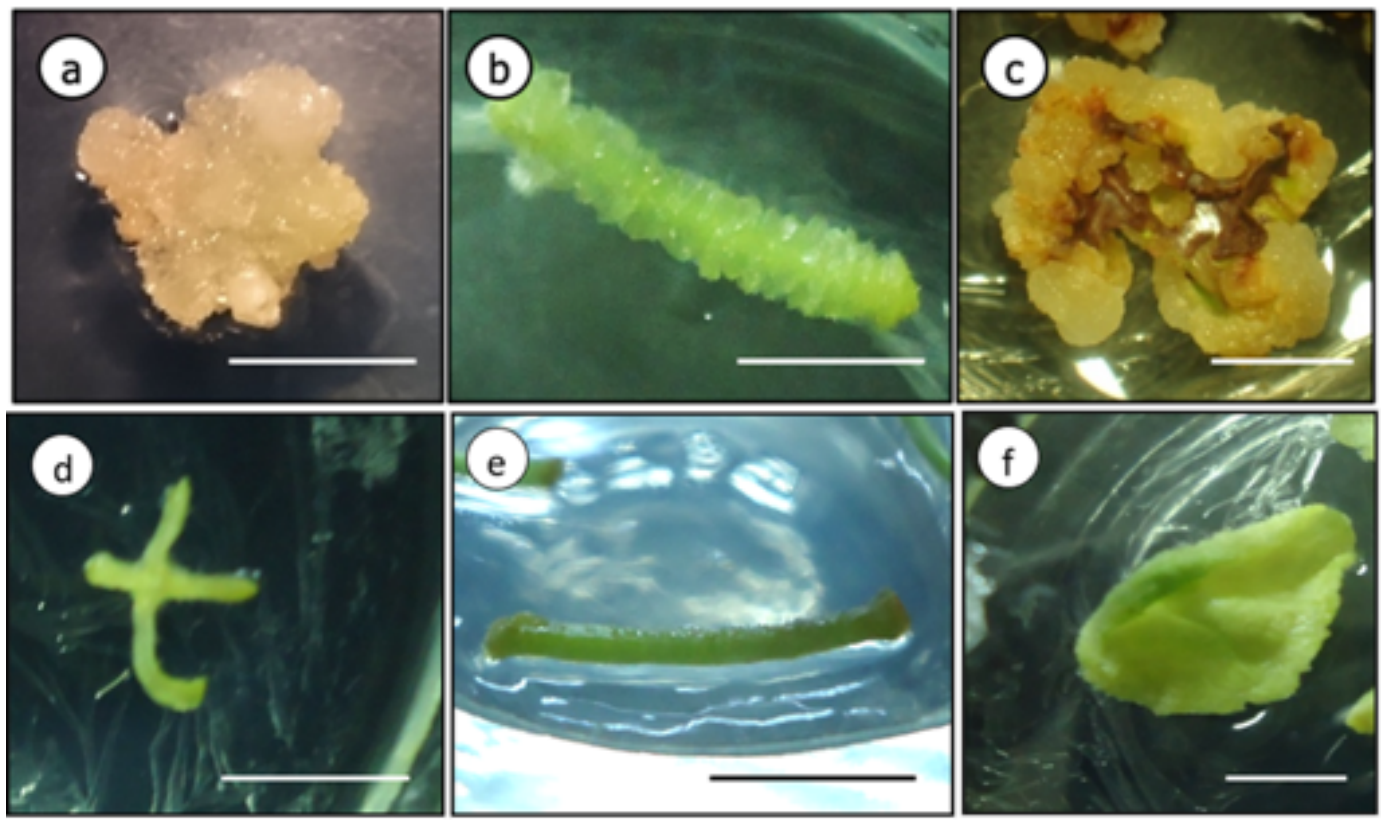

Gambar 1. Induksi kalus primer stevia dengan eksplan buku (a), ruas (b), dan daun (c) pada perlakuan auksin. Kalus tidak terbentuk pada media tanpa auksin dari eksplan buku (d), ruas (e), dan daun (f). Skala garis $=5 \mathrm{~mm}$

Figure 1. Initial callus induction of stevia from node (a), internode (b), and leaf (c) explants with auxin treatment. Callus cannot be formed on medium without auxin from node (d), internode (e), and leaf $(f)$ explant. Bar scale $=5 \mathrm{~mm}$
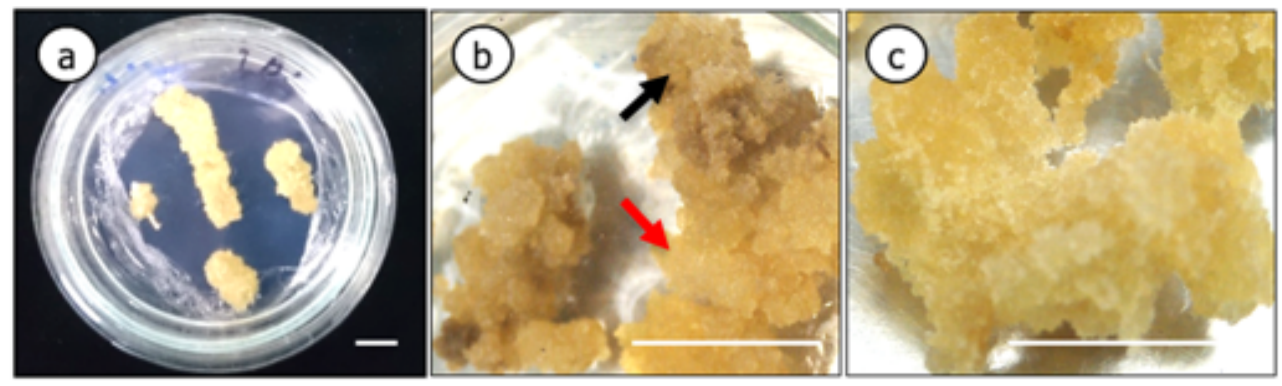

Gambar 2. Induksi kalus stevia. Kalus muncul pada seluruh permukaan eksplan (a), kalus campuran yang terdiri dari kalus kompak (anak panah berwarna merah) dan kalus remah (anak panah berwarna hitam) (b), dan kalus remah terseleksi (c). Skala garis $=5 \mathrm{~mm}$

Figure 2. Callus induction of stevia. Calli appeared on all surfaces of the explant (a), mixed calli consist of compact callus (red arrow) and friable callus (black arrow) (b), and selected friable calli (c). Bar scale $=5 \mathrm{~mm}$ 
potensi embriogenik yang lebih baik dibandingkan kalus kompak (Mwaniki et al., 2019). Oleh karena itu, kalus inilah yang digunakan untuk tahap kultur selanjutnya.

Kalus primer stevia berupa kalus dengan struktur lunak berwarna bening atau translusen. Kalus bening muncul pada seluruh permukaan eksplan, kecuali pada eksplan daun, kalus muncul pada bagian tepi eksplan yang bersentuhan langsung dengan media (Gambar 1). Penggunaan 3,4-D pada induksi kalus stevia merupakan hal baru, umumnya 3,4-D digunakan untuk induksi kalus pada tanaman karet (Montoro et al., 2012). Ketiga jenis eksplan menghasilkan kalus yang cukup baik untuk dapat dikultur ke tahap selanjutnya.

Kalus terseleksi dari tahap sebelumnya kemudian diproliferasi pada media MS dengan komposisi yang sama (media induksi). Penambahan $\mathrm{CaCl}_{2}$ pada konsentrasi 2, 4, 8, dan $16 \mathrm{mM}$ dilakukan untuk meningkatkan keremahan (friability) dan proliferasi kalus. Hasil penelitian menunjukkan bahwa penambahan $\mathrm{CaCl}_{2} 16 \mathrm{mM}$ pada media dengan penambahan 3,4-D $1 \mu \mathrm{M}$ meningkatkan proliferasi kalus hingga 4,7 kali
(Gambar 3 \& 4). Proliferasi kalus terendah terdapat pada media dengan penambahan 2,4-D 2,5 $\mu \mathrm{M}$ dikombinasikan dengan $\mathrm{CaCl}_{2}$ berkonsentrasi 2,8 maupun $16 \mathrm{mM}$ serta 3,4-D 2,5 $\mu \mathrm{M}$ dikombinasikan $\mathrm{CaCl}_{2} 4 \mathrm{mM}$.

Penggunaan $\mathrm{CaCl}_{2}$ dengan perlakuan auksin memberikan warna yang baik (kuning). Warna kalus merupakan gambaran visual yang dijadikan sebagai indikator perkembangan eksplan pada kultur in vitro sehingga dapat diketahui bahwa kultur kalus yang terbentuk sel-selnya masih aktif membelah atau mati. Kalus embriogenik dicirikan dengan warna yang putih kekuningan dengan permukaan yang mengkilat (Lizawati, 2012) sehingga kalus yang berwarna kekuningan diduga potensial membentuk kalus embriogenik. Pada penambahan $\mathrm{CaCl}_{2}$ dengan konsentrasi hingga $12 \mathrm{mM}$ masih mampu memproduksi lini sel kalus remah (cell line) tanpa kalus kompak, namun belum menghasilkan kalus noduler, sehingga perlu dilakukan percobaan untuk induksi kalus noduler embriogenik. Penambahan $\mathrm{CaCl}_{2} \quad(9 \mathrm{mM})$ dikombinaskan dengan 3,4-D $(1,34 \mu \mathrm{M})$ juga dilakukan pada proliferasi kalus karet (Lardet et al., 2009).

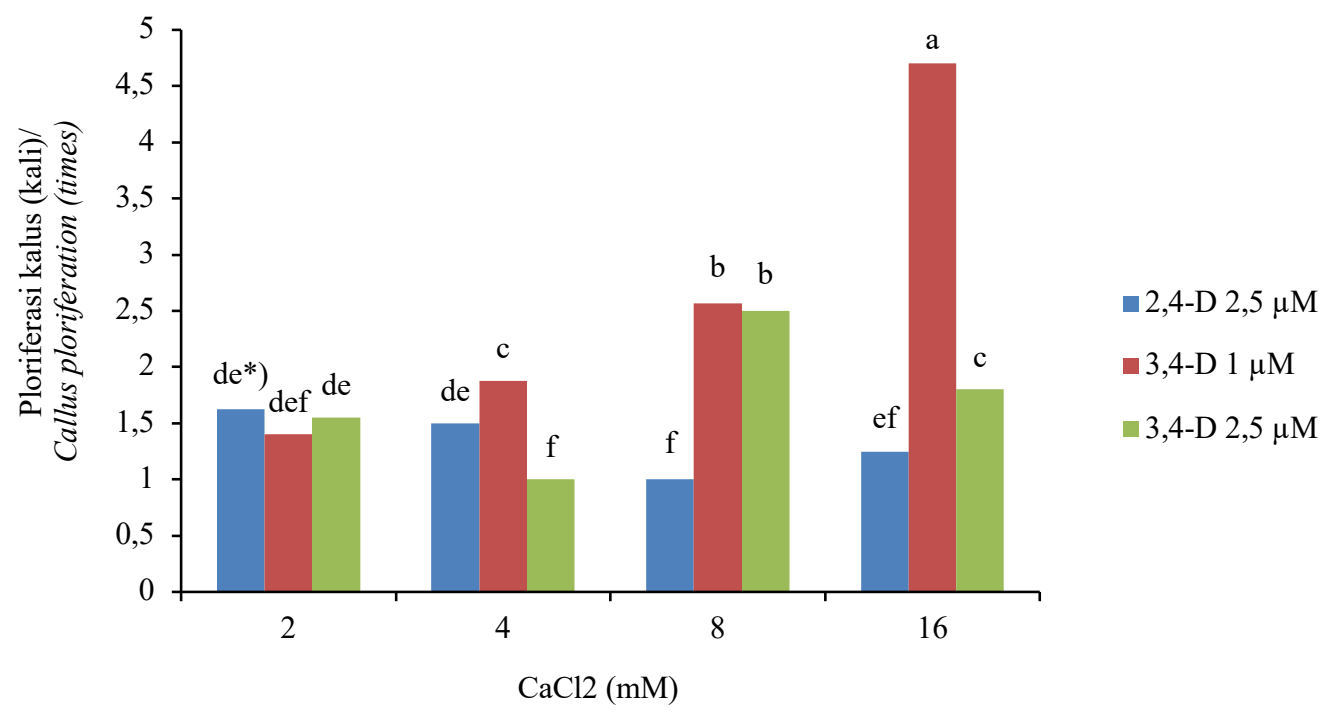

Gambar 3. Laju proliferasi kalus stevia pada media MS dengan penambahan $\mathrm{CaCl}_{2}$ pada konsentrasi 2; $4 ; 8$ dan $16 \mathrm{mM}$ serta 2,4-D 2,5 $\mu \mathrm{M}, 3,4-\mathrm{D} 1 \mu \mathrm{M}$, dan 2,5 $\mu \mathrm{M}$

Figure 3. Proliferation of stevia calli on MS media added with $\mathrm{CaCl}_{2}$ at 2; 4; 8 and $16 \mathrm{mM}$ and 2,4-D 2,5 $\mu M, 3,4-\mathrm{D} 1$ $\mu M$, and $2.5 \mu M$

*) Angka yang diikuti oleh huruf yang sama berarti tidak berbeda nyata menurut uji jarak berganda Duncan pada $\mathrm{P}=0,05$

$\left.{ }^{*}\right)$ Means followed by the same letter are not significantly different according to Duncan's multiple range test at $P=0.05$ 


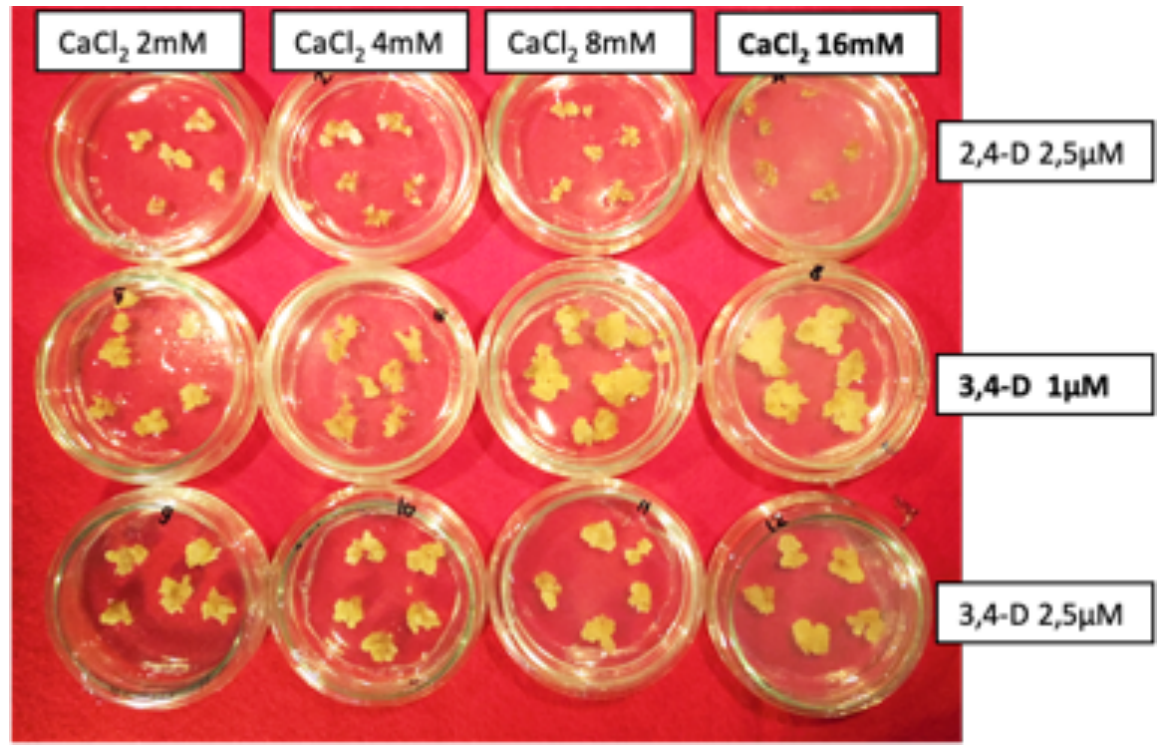

Gambar 4. Pengaruh $\mathrm{CaCl}_{2}$ dan auksin terhadap friablitas serta proliferasi kalus stevia pada 3 minggu setelah kultur Figure 4. Effect of $\mathrm{CaCl}_{2}$ and auxins on friability and proliferation of stevia calli at 3 weeks after culture

\section{Kalus embriogenik}

\section{Pengaruh sitokinin}

Pada percobaan pertama induksi embrio somatik digunakan 3,4-D dengan konsentrasi $0,5 \mu \mathrm{M}$ dikombinasikan dengan sitokinin (kinetin, 2-iP, BA) masing-masing pada konsentrasi 0,5 , 10 , dan $20 \mu \mathrm{M}$. Setelah inkubasi selama 4 minggu, penggunaan BA $20 \mu \mathrm{M}$ menghasilkan tekstur kalus terbaik yaitu remah, warna kekuningan, dan proliferasi sangat tinggi, namun belum terbentuk embrio somatik (Gambar 5a). Kalus noduler dihasilkan pada medium dengan penambahan BA $10 \mu \mathrm{M}$ (Gambar 5b). Untuk induksi embrio somatik lebih lanjut, kalus embriogenik tersebut selanjutnya disubkultur ke medium yang sama, lalu diinkubasi di ruang kultur gelap dan ruang kultur terang untuk melihat responsnya terhadap cahaya. Setelah tiga minggu, kalus pada medium dengan konsentrasi BA $10 \mu \mathrm{M}$ yang diinkubasi pada ruang kultur terang menghasilkan struktur noduler berwarna kehijauan (Gambar 5c). Struktur noduler kehijauan ini memiliki potensi untuk melakukan regenerasi, baik membentuk embrio somatik maupun membentuk tunas adventif melalui organogenesis. Penggunaan sitokinin lain yakni kinetin dan 2-iP belum mampu menginduksi kalus noduler.

\section{Pengaruh sumber dan konsentrasi karbon}

Medium dasar yang digunakan pada penelitian ini adalah medium MS dengan hormon 3,4-D $0,5 \mu \mathrm{M}$ dan kinetin $5 \mu \mathrm{M}$. Sumber karbon yang digunakan yaitu sukrosa, maltosa, glukosa, dan manitol dengan konsentrasi masing-masing 30, 60, 90, dan $120 \mathrm{gL}^{-1}$. Hasil penelitian menunjukkan bahwa penggunaan maltosa mampu mempertahankan friabilitas kalus baik pada konsentrasi 30, 60, 90 maupun $120 \mathrm{gL}^{-1}$ (Tabel 2). Penggunaan manitol pada konsentrasi hingga
$90 \mathrm{gL}^{-1}$ masih menghasilkan kalus remah, namun pada konsentrasi $120 \mathrm{gL}^{-1}$ menghasilkan kalus campuran. Penggunaan sukrosa mampu mempertahankan friabilitas kalus hanya pada konsentrasi $30 \mathrm{gL}^{-1}$. Akan tetapi pada konsentrasi lebih tinggi, kalus remah sebagian menjadi kompak. Penggunaan sumber karbon glukosa menghasilkan kalus campuran pada semua tingkat konsentrasi. Maltosa juga merupakan sumber karbohidrat terbaik untuk induksi embrio somatik pada tanaman karet dari eksplan integumen-dalam (Blanc et al., 1999) serta jeruk (Widoretno et al., 2017), walaupun sukrosa $30 \mathrm{gL}^{-1}$ juga dilaporkan baik untuk SE karet dengan eksplan anther (Modeste et al., 2012). Selain berfungsi sebagai sumber karbon, maltosa juga dilaporkan memiliki peranan osmotik untuk perkembangan embrio bawang putih (Nasim et al., 2010). Perlakuan sumber dan konsentrasi karbon belum berhasil menginduksi terbentuknya embrio somatik pada stevia, namun kombinasi jenis karbon disarankan untuk dikaji lebih lanjut.

\section{Pengaruh pencucian}

Kalus remah klon BX asal buku dari penelitian pertama disubkultur ke medium cair MS tanpa hormon dengan tujuan menyerap hormon yang telah ada dalam eksplan dari perlakuan sebelumnya, mengingat eksplan yang jenuh terhadap hormon tidak mampu berkembang lebih lanjut. Kultur pada medium cair dilakukan selama satu minggu, kemudian dipindahkan ke medium padat MS dengan setengah konsentrasi hara makro tanpa hormon, dan MS dengan setengah hara makro ditambah IBA $10 \quad \mu \mathrm{M}$ seperti yang dilakukan oleh Beneerje \& Sarkar (2010), dan diinkubasi selama empat minggu di ruang kultur gelap. Setelah empat minggu, muncul kalus sekunder yang noduler pada medium padat tanpa penambahan IBA, 3\% dari medium cair tanpa 
hormon, dan 53\% dari medium cair yang masih menggunakan hormon. Sedangkan pada medium padat dengan penambahan IBA, 90\% membentuk kalus noduler baik dari medium cair tanpa hormon maupun dengan penambahan hormon (Tabel 3,
Gambar 6). Dengan demikian, untuk membentuk kalus noduler atau embriogenik, kultur stevia tetap memerlukan penggunaan hormon. Transfer ke medium cair dengan penambahan IBA juga meningkatkan pembentukan kalus noduler.
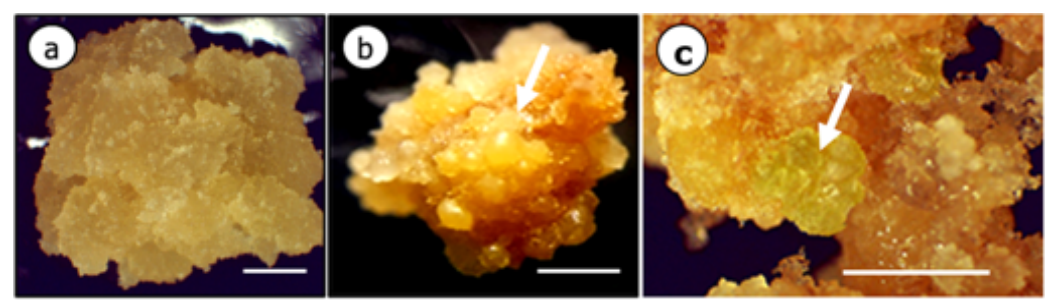

Gambar 5. Lini sel kalus remah pada media dengan BA $20 \mu \mathrm{M}$ (a), dan kalus noduler pada media dengan BA $10 \mu \mathrm{M}$ pada ruang gelap (b) dan terang (c). Skala garis $=5 \mathrm{~mm}$

Figure 5. Friable callus cell line on medium with BA $20 \mu M($ a), and nodular calli from medium with BA $10 \mu M$ on dark room (b), light room (c). Bar scale $=5 \mathrm{~mm}$

Tabel 2. Pengaruh jenis dan konsentrasi sumber karbon terhadap perkembangan kalus stevia

Table 2. Effect of type and concentration of carbon sources on callus development of stevia

\begin{tabular}{|c|c|c|c|}
\hline $\begin{array}{l}\text { Jenis sumber karbon } \\
\text { Carbon sources }\end{array}$ & $\begin{array}{c}\text { Konsentrasi } \\
\text { Concentration } \\
\left(\mathrm{gL}^{-1}\right)\end{array}$ & $\begin{array}{l}\text { Tipe kalus } \\
\text { Callus type }\end{array}$ & $\begin{array}{l}\text { Warna kalus } \\
\text { Callus color }\end{array}$ \\
\hline \multirow{4}{*}{ Sukrosa/ Sucrose } & 30 & Remah & Kekuningan \\
\hline & 60 & Campuran & Kecoklatan \\
\hline & 90 & Campuran & Kecoklatan \\
\hline & 120 & Campuran & Coklat \\
\hline \multirow{4}{*}{ Glukosa/ Glucose } & 30 & Campuran & Krem \\
\hline & 60 & Campuran & Kecoklatan \\
\hline & 90 & Campuran & Kecoklatan \\
\hline & 120 & Campuran & Coklat \\
\hline \multirow{4}{*}{ Maltosa/ Maltose } & 30 & Remah basah & Kekuningan \\
\hline & 60 & Remah basah & Kecoklatan \\
\hline & 90 & Remah basah & Kecoklatan \\
\hline & 120 & Remah basah & Kecoklatan \\
\hline \multirow{4}{*}{ Manitol/Mannitol } & 30 & Remah basah & Krem, coklat \\
\hline & 60 & Remah basah & Kecoklatan \\
\hline & 90 & Remah basah & Kecoklatan \\
\hline & 120 & Campuran & Coklat \\
\hline
\end{tabular}

Keterangan/Note: Remah=Friable; Campuran=Mixed; Remah basah=Watery friable; Kekuningan=Yellowish; Krem= Beige; Coklat $=$ Brown Kecoklatan $=$ Brownish .

Table 3. Pengaruh pencucian dan media tanam terhadap pembentukan kalus noduler

Table 3. Effect of washing and culture medium on nodular callus formation

\begin{tabular}{ccc}
\hline $\begin{array}{c}\text { Media pencucian / } \\
\text { Washing medium }\end{array}$ & $\begin{array}{c}\text { Media penanaman/ } \\
\text { Culture medium }\end{array}$ & $\begin{array}{c}\text { Kalus noduler (\%)/ } \\
\text { Noduler callus (\%) }\end{array}$ \\
\hline $1 / 2 \mathrm{MS}$ & $1 / 2 \mathrm{MS}$ & 3 \\
$1 / 2 \mathrm{MS}$ & $1 / 2 \mathrm{MS}+\mathrm{IBA} 10 \mu \mathrm{M}$ & 90 \\
$1 / 2 \mathrm{MS}+\mathrm{IBA} 10 \mu \mathrm{M}$ & $1 / 2 \mathrm{MS}$ & 53 \\
$1 / 2 \mathrm{MS}+\mathrm{IBA} 10 \mu \mathrm{M}$ & $1 / 2 \mathrm{MS}+\mathrm{IBA} 10 \mu \mathrm{M}$ & 90 \\
\hline
\end{tabular}




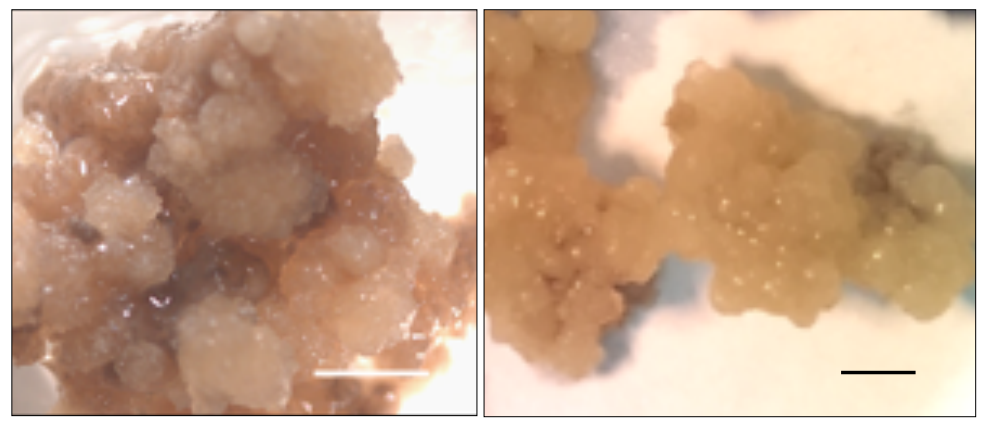

Gambar 6. Pembentukan kalus noduler stevia (skala garis $=5 \mathrm{~mm}$ )

Figure 6. Formation of stevia nodular callus (bar $=5 \mathrm{~mm}$ )

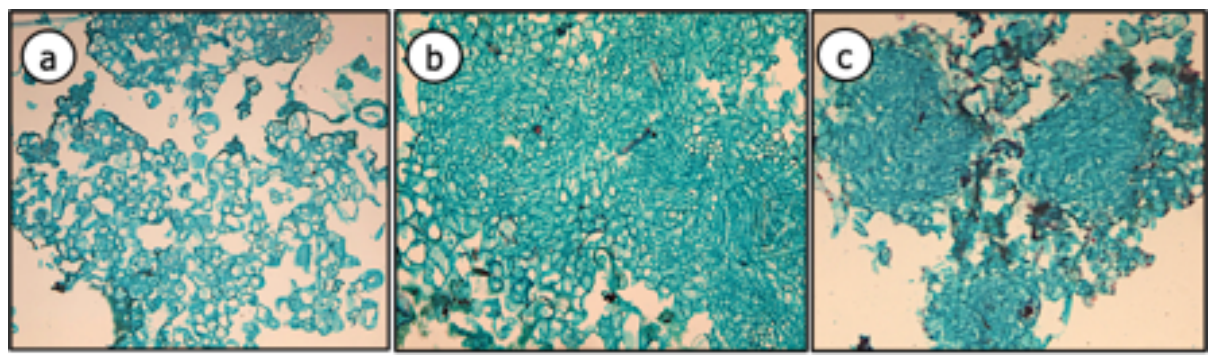

Gambar 7. Histologi kalus stevia: kalus remah (a), kalus noduler (b), dan kalus noduler hijau (c). Skala garis $=0,1 \mathrm{~mm}$

Figure 7. Histology of stevia calli: friable calli (a), nodular calli (b), and greenish nodular calli (c). Bar $=0.1 \mathrm{~mm}$

\section{Histologi}

Analisis histologi dilakukan pada kalus remah, kalus noduler yang diperoleh dari penelitian pada medium cair, serta kalus noduler kehijauan dari kultur terang. Kajian histologi ini dilaksanakan untuk mengamati potensi kalus embriogenik untuk membentuk embrio somatik. Berdasarkan hasil analisis histologi, sel-sel yang membentuk kalus remah stevia terlihat longgar, vakuola lebih besar, dan lebih homogen yang merupakan ciri khas dari kalus berupa massa sel yang tidak terdiferensiasi (Gambar 7a). Pada kalus noduler sel-sel berukuran lebih kecil mulai memadat, sitoplasma rapat, dan vakuola mengecil yang merupakan ciri awal dari kalus yang terdiferensiasi, serta membentuk klaster yang lebih jelas (Gambar 7b). Pertumbuhan sel-sel yang membentuk klaster semakin memusat terlihat dari warna penampang histologi yang menunjukkan sitoplasma sel yang semakin pekat pada kalus noduler hijau (Gambar 7c). Oleh karena itu, diharapkan kalus noduler ini akan berkembang lebih lanjut menjadi embrio somatik melalui embriogenesis somatik tak-langsung.

\section{Kesimpulan}

Kalus telah berhasil diinisiasi dengan persentase pembentukan kalus lebih dari 70\% dari eksplan daun, buku dan ruas dari tanaman stevia klon BX. Kalus remah lini sel (cell line) stevia telah didapatkan pada penelitian ini. Penggunaan 3,4-D $1 \mu \mathrm{M}$ dan $\mathrm{CaCl}_{2} 16 \mathrm{mM}$ direkomendasikan untuk meningkatkan proliferasi kalus remah hingga 4,7 kali dalam waktu 3 minggu dengan tetap menjaga kualitas kalus remah. Penggunaan hormon BA $10 \quad \mu \mathrm{M}$ dan pencucian serta penanaman pada media $1 / 2$ MS dan IBA $10 \mu \mathrm{M}$ mampu menghasilkan kalus noduler. Kajian histologi menunjukkan kedua jenis kalus ini telah terdiferensiasi sehingga memiliki potensi untuk berkembang lebih lanjut menjadi embrio somatik.

\section{Ucapan Terima Kasih}

Ucapan terima kasih kepada Program Kerjasama Kemitraan Penelitian dan Pengembangan Pertanian Nasional (KKP3N) tahun 2015 Kementerian Pertanian atas pendanaan riset yang diberikan.

\section{Daftar Pustaka}

Apio HB, T Alicai, Y Baguma, SB Mukasa, A Bua \& N Taylor (2015). Production of friable embryogenic callus and regeneration of Ugandan farmer-preferred cassava genotypes. Afr J Biotechnol 14(22), 1854-1864.

Banerjee M \& P Sarkar (2008). In vitro callusing in Stevia rebaudiana Bertoni using cyanobacterial media - a novel approach to tissue culture. Internat J Integrative Biol 8(3), 163-168.

Banerjee M \& P Sarkar (2010). Somatic embryogenesis in Stevia rebaudiana Bertoni using different concentration of growth hormones. Internat J Plant Sci 5(1), 284-289.

Blanc G, N Michaux-Ferriere, C Teisson, L Lardet \& MP Carron (1999). Effects of carbohydrate 
addition on the induction of somatic embryogenesis in Hevea brasiliensis. Plant Cell Tiss Organ Cult 59, 103-112.

Brandle JE \& PG Telmer (2007). Steviol glycoside biosynthesis. Phytochem 68, 1855-1863.

Cailloux F, J Julien-Guerrier, L Linossier \& A Coudret (1996). Long-term somatic embryogenesis and maturation of somatic embryos in Hevea brasiliensis. Plant Sci 120, 185-196.

Ceunen S \& J Geuns (2013). Steviol glycosides: Chemical diversity, metabolism, and function. J Nat Prod 76, 1201-1228.

Cramer B \& R Ikan (1986). Sweet glycosides from the stevia plant. Chem Br 22(10), 915-917.

Dafalla HM, AM Elsheikh, HA Ali \& MM Khafalla (2019). Callus maintenance and cell line selection of Grewia tenax. J Herbs Spices Med Plants 25(3), 218-235.

Egertsdotter U, I Ahmad \& D Clapham (2019). Automation and scale up of somatic embryogenesis for commercial plant production, with emphasis on conifers. Front Plant Sci 10, 109.

Gawel-Beben K, T Bujak, Z Niziol-Lukaszewska, B Antosiecwicz, A Jakubczyk, M Karas \& K Rybcznska (2015). Stevia rebaudiana Bert. leaf extracts as a multifunctional source of natural antioxidants. Molecules 20, 5468-5486.

Goettemoeller J \& A Ching (1999). Seed germination in Stevia rebaudiana, p. 510-511. In: J Janick (ed.) Perspective on New Crops and New Uses. ASHS Press, Alexandria, VA.

Janarthanam B, M Gopalakrishnan, G Lakshmi Sai \& T Sekar (2009). Plant regeneration from leaf derived callus of Stevia rebaudiana Bertoni. Plant Tiss Cult Biotechnol 19(2), 133-141.

Jin CS \& CL Keng (2013). Factors affecting the selection of callus cell lines and the preparation of the cell suspension culture of Artemisia annua L. Plant Tissue Cult \& Biotech 23(2), 157-163.

Keshvari T, A Najaphy, D Kahrizi \& A Zebarjadi (2018). Callus induction and somatic embryogenesis in Stevia rebaudiana Bertoni as a medicinal plant. Cell Mol Biol 64(2), 46-49

Kumar R, S Sharma \& S Sood (2014). Yield components, light interception and marker compound accumulation of stevia (Stevia rebaudiana Bertoni) affected by planting material and plant density under western Himalayan conditions. Arch Agron Soil Sci 1, $1-15$.

Lardet L, F Dessailly, MP Carron, MA Rio, N Ferreire \& P Montoro (2009). Secondary somatic embryo in Hevea brasiliensis (Mull. Arg.): An alternative process for long-term somatic embryogenesis. J Rubb Res 12(4), 215228.

Lardet L, F Martin, F Desailly, MP Carron \& P Montoro (2007). Effect of exogenous calcium on post-thaw growth recovery and subsequent plant regeneration of cryopreserved embryogenic calli of Hevea brasiliensis (Mull. Arg.). Plant Cell 26, 559-569.

Lelu-Walter MA, F Gautier F, K Eliášová, L Sanchez, C Teyssier, AM Lomenech, CL Metté, C Hargreaves, JF Trontin \& C Reeves (2018). High gellan gum concentration and secondary somatic embryogenesis: Two key factors to improve somatic embryo development in Pseudotsuga menziesii. Plant Cell Tissue Organ Cult 132, 137-155.

Lemus-Mondaca, A Vega-Galvez, P Rojas, K Stucken, S Delporte, G Valenzuela-Barra, RJ Jagus, MV Aguero \& A Pasten (2018). Antioxidant, antimicrobial and antiinflammatory potential of Stevia rebaudiana leaves: effect of different drying methods. $J$ Appl Res Medicinal and Aromatic Plants 11, 37-46.

Lizawati (2012). Induksi kalus embriogenik dari eksplan tunas apikal tanaman jarak pagar (Jatropha curcas L.) dengan penggunaan 2,4D dan TDZ. Bioplantae 1(2), 75-87.

Lopez-Arellano M, S Dhir, NC Albino, A Santiago, T Morris \& SK Dhir (2015). Somatic embryogenesis and plantlet regeneration from protoplast culture of Stevia rebaudiana. Bristish Biotechnol J 5(1), 1-12.

Mengesha B, W Geja \& Z Damtew (2014). Stevia production guidelines. Ethiopian Institute of Agricultural Research, Ethiopia.

Modeste KK, KK Edmond, KN Gilles, G Michel, K Mongomaké, KT Hilaire (2012). Callogenesis and somatic embryogenesis induction in Hevea brasiliensis: effects of fruit shelf-life and carbon source. Res in Biotechnol $3(6), 42-50$.

Montoro P, MP Carron, F Granet, L Lardet \& J Leclercq (2012). Development of new varietal types based on rejuvenation by somatic embryogenesis and propagation by conventional budding or microcutting in Hevea brasiliensis. CIBA Workshop 22-24 October 2012.

Murashige T \& F Skoog (1962). A revised medium for rapid growth and bioassays with tobacco tissue culture. Physiol Plant 15, 473-497.

Mwaniki WI, AH Lubabali, KK Asava, CO Agwanda \& SE Anami (2019). Effect of genotype and plant growth regulators on callus 
induction in leaf cultures of Coffea arabica $\mathrm{L}$. F1 hybrid. African J Biotechnol 18(31), 10041015.

Nasim SA, A Mujib, R Kapoor, S Fatima, J Aslam \& Mahmooduzzafar. (2010). Somatic embryogenesis in Allium sativum L. (cv. Yamuna Safed 3): Improving embryo maturation and germination with PGRs and carbohydrates. Anales de Biol 32, 1-9.

Oliveira AJB, LMC Cordeiro, RAC Goncalves,LF Ceole, T Ueda-Nakamura, M Lacomini (2013). Structure and antiviral activity of arabinogalactan with $(1 \rightarrow 6)-\beta$-D-galactan corefrom Stevia rebaudiana leaves. Carbohydrate Polymers 94, 179-184.

Ozyigit Y, E Ucar \& K Turgut (2015). The effect of different pollination methods on seed yield and germination features in Stevia rebaudiana Bertoni. Turk JU Agric Res 21, 114-117.

Parris CA, CC Shock, M Qian (2016). Dry leaf and steviol glycoside productivity of Stevia rebaudiana in the Western United States. HortSci 51(10), 1220-1227.

Pérez E, C González, F Vaillant \& M Lares (2016). Stevia derivative and its potential uses in diabetic-directed foods review. $J$ Nutrients 3(1), 1-20.

Pikulthong V, T Teerakathi, A Thamchaipenet \& S Peyachoknagul (2016). Development of somatic embryos for genetic transformation in Curcuma longa L. and Curcuma mangga Valeton \& Zijp. Agric Nat Res 50(4), 276-285.

Pires R, HCardoso, A Ribeiro, A Peixe \& A Cordeiro (2020). Somatic embryogenesis from mature embryos of Olea europaea L. cv. 'Galega Vulgar' and long-term management of calli morphogenic capacity. Plants 9, 758.

Prakash I, A Markosyan \& C Bunders (2014). Development of next generation stevia sweetener: Rebaudioside M. Molecules 3, 162175.

Raina R, SK Bhandari, R Chand \& Y Sharma (2013). Strategies to improve poor seed germination in Stevia rebaudiana, a low calorie sweetener. J Medicinal Plants Res 7(24), 17931799.

Ramulifho E, T Goche, J van As, TJ Tsilo, S Chivasa \& R Ngara (2019). Establishment and characterization of callus and cell suspension cultures of selected Sorghum bicolor (L.) Moench varieties: A resource for gene discovery in plant stress biology. Agronomy 9, $1-18$.

Ribas AF, E Dechamp, A Champion, B Bertrand, MC Combes, JL Verdeil, F Lapeyre, P Lashermes \& H Etienne (2011). Agrobacterium-mediated genetic transformation of Coffea arabica (L.) is greatly enhanced by using established embryogenic callus cultures. BMC Plant Biol 11(92), 1-15.

Ruzin SE (1999). Plant Microtechnique and Microscopy. Oxford University Press. 322p.

Sinta MM \& Sumaryono (2019). Pertumbuhan, produksi biomassa, dan kandungan glikosida steviol lima klon introduksi stevia di Bogor, Indonesia. J Agron Indonesia 47(1), 104-109.

Souza JMM, S Berkov \& AS Santos (2014). Improvement of friable callus production of Boerhaavia paniculata Rich and the investigation of its lipid profile by GC/MS. An Acad Bras Cienc 86(3), 1015-1027.

Wang G, C Xu, S Yan \& B Xu (2019). An efficient somatic embryo liquid culture system for potential use in large-scale and synchronic production of Anthurium andraeanum seedlings 10, 29.

Widoretno W, S Indriyani, C Martasari \& R Hakin (2017). Effects of sugar type and concentration on Batu 55 Mandarin (Citrus reticulata Blanco.) somatic embryo maturation. Agrivita 39(1), 100-110.

Yadav AK, S Singh \& Rajeev (2014). Selfincompatibility evidenced through scanning electron microscopy and pollination behaviour in Stevia rebaudiana. Indian J Agric Sci 84 (1), 93-100 